${ }^{3}$ Registrar General. Decennial supplement for England and Wales 1961. Occupational mortality tables. London: HMSO, 1971.

4 Registrar General. Decennial supplement for England and Wales 1970-72. Occupational mortality. London: HMSO, 1978. (OPCS Series DS No 1.)

${ }^{5}$ King H, Bailar JC III. Mortality among Lutheran clergymen. Milbank Mem Fund $Q$ 1968;46:527-48.

${ }^{6} \mathrm{King} \mathrm{H}$. Health in the medical and other learned professions. $\mathcal{F}$ Chronic Dis $1970 ; 23: 257-81$.

${ }^{7}$ King H. Clerical mortality patterns of the Anglican communion. Soc Biol 1971;18:164-77.

${ }^{8}$ King H, Zafros G, Hass R. Further inquiry into Protestant clerical mortality patterns. F Biosoc Sci $1975 ; 7: 243-54$.

9 Locke FB, King H. Mortality among Baptist clergymen. $f$ Chronic Dis 1980 ;33:581-90.

\section{More anthropology and less sleep for medical students}

Young graduates from different medical schools have more similarities than differences. Those from ancient institutions seem indistinguishable in attitudes and attainments from the products of schools in which the paint is not dry and the second professor of surgery not yet born. Yet great battles are fought over what subjects should be taught. The alleycats of psychology, sociology, epidemiology, statistics, anthropology, communications studies, computer science, and even general practice and community medicine are hardly visible for flying fur in the scrap for time and status. Meanwhile, the lions and tigers of medicine-surgery, anatomy, physiology, and the like - count their blessings and guard their cubs. If the shrinking gap between full qualification and retirement is not to disappear altogether and students are to be allowed to sleep at nights then faculties must consider carefully what they want to teach.

Medical anthropologists are the latest group to raise their voices asking for room in the curriculum. A joint meeting in Edinburgh of the British Medical Anthropology Society and the sibilant Edinburgh Transcultural Psychiatry Society suggested that medical students could learn much that was useful from social anthropology. As Professor J E Cooper from Nottingham pointed out, there are no scientific studies to tell us whether more neuroanatomy or more medical anthropology makes better doctors (nor, indeed, whether more anatomy and less rugby does-some would doubt it). Therefore we must assess the medical anthropologists' arguments (good) and feel the strength of their political muscle (weak).

What is anthropology and why should medical students be exposed to it ? (They cannot be taught it in the time available.) Definitions of anthropology are vague: a common one, that it is the science of man in its widest sense, might be said to include the whole of medicine; another, that it is the study of man in his environment, makes its exclusion from medical school curricula seem remarkable. An often-repeated comment on anthropology - that it is the most scientific of the humanities and the most humane of the sciences-seems to place it right alongside medicine. Medical anthropology is better defined as "what medical anthropologists do," and they do a lot: they study different cultures' beliefs about illness, health, and treatment; health care organisation; and the behaviour of various groups (for instance, doctors and patients), and the communication among them. The groups studied include not only the inhabitants of exotic islands but also, as papers presented at the conference made clear, ordinary people-patients in a Middlesex general practice, Aberdonian fishwives, and the Parisian jet set. Anthropological methods are designed less to measure and more to "get under the skin" of the group being studied; classically, an anthropologist will live among the people he is studying, speak and eat as they do, and fit in as much as possible. Anthropological studies are often lists of quotations rather than statistics-a change that may be refreshing for the student more interested in people than science.

Teaching anthropology in medical schools could be seen as remedial education for the middle classes: for a doctor educated at Westminster, Cambridge, and Guy's a football-obsessed Mancunian may be as strange as a Zulu. At the conference $\mathrm{Dr}$ Cecil Helman's paper on patients in a general practice and $\mathrm{Dr}$ Mildred Blaxter's paper describing the ideas about illness of two generations of working class Aberdeen women showed that these groups have complex ideas about illness, its causes, and its treatment. These ideas are often quite different from those of doctors, who no matter where they are practising will only benefit from understanding the patient's beliefs. In such areas as the East End of London-where, as Dr Jane Jackson described, such diverse groups as orthodox Jews, Pakistanis, Rastafarians, National Front enthusiasts, art students, "winos," and a few remnant cockneys live-doctors will find it hard to treat effectively without some insight into these people's views of illness and health; and this can best be achieved through anthropology. Also studies of doctors' behaviour, reactions to modern hospitals, and cultural variations in attitude to mental illness can give breadth to the thinking of students.

The introduction of anthropology along with many other less traditional disciplines into the curriculum is resisted in many medical schools. The usual argument is that this would be all very well but there is simply no time available. Professor Cooper thought that other problems were that doctors, academics, and surgeons are themselves legitimate subjects for anthropological study and they may find this threatening. Furthermore, anthropology is more concerned with values and attitudes than "facts," which have traditionally been the main substance of the medical curriculum. But in some medical schools-for instance, Aberdeen-the students have asked to be taught anthropology-though sometimes when it arrives they find it hard to comprehend. Professor Cooper suggested from his experience in Nottingham that it could best be taught by generalists in small doses using mostly medical examples.

Certainly medical students would benefit from learning to see illness and modern medicine from the patients' point of view. One thing not mentioned at the conference, however, is that another way of understanding something of how others see the world is by reading novels, which almost by definition are easier to read than anthropology. Works by authors such as Dickens, Wesker, Steinbeck, Orwell, Zola, Sillitoe, Berger, and Dostoevsky both entertain and educate.

\section{An endangered species}

Among the species registered as endangered in the coming decade should be included the independent expert-in its habitat as adviser to Government. One threat has come from Mr Patrick Jenkin. Twice this year he has rejected reports based on external analysis of medicosocial needs: on in equalities in health ${ }^{1}$ and on perinatal mortality. ${ }^{2}$ Perhaps flat, insensitive rejection of independent outside assessments is part of his personal philosophy: but the long-term result must be a further devaluation of the status of scientific 
judgment-while no expert in his or her senses will want to agree to give time to further advisory work on behalf of the DHSS while such attitudes persist.

Sir Douglas Black's working group on inequalities in health was set up in 1977 by the Labour Government. Its four members assembled a vast mass of data. Their main finding was that in the 1960s and 1970s the health of the poorer sections of our society did not improve and in some respects deteriorated. Their recommendations were intended to give children a better start in life and to encourage good health among a larger proportion of the population. Much of the emphasis was on preventive approaches, education, and sustained drive against child poverty.

$\mathrm{Mr}$ Jenkin clearly did not like the report. His dismissive foreword claimed that the recommendations would cost upwards of $£ 2000$ million a year and that they were quite unrealistic "in present or any foreseeable economic circumstances." The Secretary of State added that he was making the report available for discussion-but since only 260 copies were printed ${ }^{3}$ that discussion has not been very wide-ranging. The report was, in plain terms, ditched.

The House of Commons' Social Services Committee examined perinatal and neonatal mortality between 1979 and 1980 , reporting last summer. ${ }^{2}$ The report was again backed by solid data, reviewed and discussed with the help of the three medical advisers. The MPs visited NHS maternity units all over the country and took evidence from hundreds of sources. Again, the main findings were the inequalities in the health of different sections in our society, and the recommendations were intended to narrow those differences.

This time Mr Jenkin has not ignored the report; instead, he has strangled it. In his reply ${ }^{4}$ he claims that he wants to "discourage unrealistic expectations which the Committee's report may have aroused of the number of deaths and serious handicaps which are avoidable and the ease with which they could be prevented." He has rejected most of the fundamental recommendations-the setting of standards and norms for staffing and equipment; the further discouragement of home delivery; an increase in the provision of neonatal intensive care unit cots and the designation of subregional perinatal centres; and a ban of tobacco advertisements and a warning of its adverse effects on cigarette packets. Other fundamental proposals-on confidential inquiries into perinatal deaths, for a differential pay incentive for midwives, and an increase in the numbers of consultant paediatricians-have been ducked by reference to health authorities and professional bodies.

Most important, $\mathrm{Mr}$ Jenkin has refused to give maternity and neonatal services the overriding priority recommended by the committee; health authorities are to be left free to make their own choices on priorities. He flatly rejects the committee's argument that the cost of its recommendations would be far outweighed by the savings they would produce. In plain terms, he refused to believe the report.

No one disputes the severity of the Government's economic problems; we would not have criticised Mr Jenkin for saying that since there is no money the proposals will have to be deferred. In both cases the experts responsible for the reports had hoped that their work might lead to a policy being adopted-a long-term strategy for the narrowing of the differences between the top and bottom layers of our society. Instead they have been told that they wasted their time. Mr Jenkin's anonymous advisers know better: the experts are wrong.

Just one year ago we complained about the flight from science ${ }^{5}$ the growing trend for politicians and the public to reject expert advice on emotional or doctrinaire grounds. 1980 has seen the trend continue: the two outstanding examples have been Debendox and brain death, where the evidence of the experts has been submerged by shock-horror journalistic techniques.

The danger for our society is that the experts are losing patience. Membership of a working party or an advisory committee (on drugs, brain death, manpower, medical education) is demanding in terms of both time and mental energy. The few really top-class advisers have many other demands on their services. They will not serve on committees whose work is discarded with the shallow indifference that is becoming common.

1 Working Group on Inequalities in Health. Report. London: HMSO, 1980. (Black Report.)

${ }^{2}$ House of Commons Social Services Committee. Session 1979-80, second report: perinatal and neonatal mortality. London: HMSO, 1980. (Short report.)

${ }^{3}$ Morris JN. Inequalities in health. Br Med f 1980;281:1003.

4 Department of Health and Social Security. Reply to the second report from the Social Services Committee on Perinatal and Neonatal Mortality. London: HMSO, 1980.

${ }^{5}$ Anonymous. The flight from science. $\operatorname{Br} \operatorname{Med} \mathcal{f} 1980 ; 280: 1-2$.

\section{Out of step}

The 1980s have started badly, not least in preventive medicine. Future generations will find it difficult to understand how successive British governments managed to remain out of step with the civilised world. There was no lack of objective evidence, but, with 100000 premature deaths every year from cigarette smoking, they countenanced the ineffectual fatuity of the new agreement with the tobacco industry, and, with some 42000 casualties associated with drink and driving, they failed to enforce the law; with the knowledge that seat belts would save a minimum of 600 deaths and 11000 serious injuries a year, they refused to introduce a Bill to make wearing them compulsory. There was no lack of evidence from other countries that such measures could be implemented: Finland, Norway, and Eire had shown that legislation could control tobacco promotion; countries as diverse as Sweden and Yugoslavia had found ways to enforce strict drink/driving laws; and virtually the whole of the rest of the civilised world passed laws to make seat-belt wearing compulsory.

If Britain is belatedly to legislate on preventive medicine, then, the impetus is likely to come from outside pressure groups rather than our elected representatives, supposedly responsible for the public health. The BMA and the royal colleges have continued their tradition of writing to ministers as well as making important public statements on health policy; Action on Smoking and Health and the Medical Council on Alcoholism are examples of established bodies concerned with a specific topic; and, encouragingly, there are signs that ad-hoc groups are being formed by local initiativeas, for example, the Wessex Positive Health Team's recent campaign for seat-belt legislation.

Individually, however, few of these bodies seem likely to be able to sustain the necessary campaigns for Britain's need for effective preventive medicine and to overcome official laissez-faire. A year ago, in discussing whether Britain needed an academy of medicine, we said that the time had come for various sections of the profession to consider combining to meet the wider medical needs. Today that need is more urgent. 